\title{
北島義和 著
}

\section{『農村レクリエーションとアクセス問題}

\section{不特定の他者と向き合う社会学』}

(京都大学学術出版会, 2018 年, A5 判, 248 頁, 3,000 円 +税)

松宮朝

(愛知県立大学教育福祉学部准教授)

本書は, アイルランド共和国の農村地域をフィールドに，土地を法的に所有する 人々と，レクリエーション活動として利用する人々との間の対立をめぐる社会学的 考察である，序章では，この対立を「農村アクセス問題」と位置づけ，土地の私的 所有権とレクリエーションの歴史を概観する。「農村アクセス問題」は，これまで 主としてコモンズ論・環境ガバナンス論で議論されてきたが，これらを「複数のア クターあるいは利用形式を伴う自然資源の管理をめぐる社会学的研究群」として 「複数的資源管理論」と名付け，(1)複数のアクター間の対話に注目する「対話アプ ローチ」，(2)自然資源をめぐるアクター間の調停のシステムに着目する「システム アプローチ」, (3)さまざまな権力の布置やそれに伴う正義に注目する「正義アプロ ーチ」という 3 つの分析視角に分類する。 そしてこれらのアプローチではとらえき れない, 対話・システム・正義の成立が困難なアイルランドの農村アクセス問題に アプローチすることの意図が示される.

第 1 章では, 20 世紀以降のアイルランド農村の変化, 1980 年代からの農村アク セスの隆盛によるウォーカーと土地所有者の対立の顕在化, これらの問題をめぐる 法的・制度的な状況, そしてアイルランド北西部のフィールドワーク地域の状況が 説明される，第 2 章では, 農村アクセス問題初期の政治プロセス, 特に管理者責任 問題, 共有地分割問題という 2 つ社会問題を通した農民たちによるフレーム戦略 と, それに伴うウォーカーの農村アクセス問題への参入に焦点があてられ， ウォー カーの農地アクセスに対する農民たちの向き合い方や実践と, それらの論理が分析 される．第 3 章では，ウォーカーを代表する 2 つの全国団体の動きとそれらをめぐ る課題を示した上で，多地点での対立や不特定多数のアクターがかかわるがゆえに 成立しがたい対話やシステム，正義／不正義の確定に対して，「農民との良好な関 係」という論理を軸にした，ウォーカーの実践の分析が行われる.「私的所有地の レクリエーション利用をめぐる作法」という章のタイトルに象徵されるように，上 述の 3 つのアプローチではとらえきることができない，不特定多数の農民を相手に する多地点的活動の「作法」を描き出すものであり，本書が対象とする事例と理論 的視角の独自性がよく表れた章となっている.

第 4 章は, 利用対象となっている土地について，農民とレクリエーション利用者 の環境認識の分析，対話の場の形成と外部アクターの影響による行き詰まり，山岳 
レスキューの分析から, 地域における生活の共有や, 対話の場とは別の契機におい て形成される, 異なる環境認識の接続回路が描き出される. 第 5 章では, 土地所有 者である農民のインタビュー調査をもとに, 農民の日常的感覚における, 生活の便 宜とは必ずしも一致しない, 不特定多数のウォーカーの農地へのアクセスが許容さ れる論理が分析される。こうした一連の分析結果の含意が，終章において「非定形 な複数的資源管理」として整理され, 対話・システム・正義が必ずしも成立しない 対立の現場における日常的実践の可能性が論じられる.

以上, 本書の内容を概観してきたが, アイルランドの事例になじみのない読者に 対しても, 豊富な写真の活用によってフィールド地域の詳細な説明がなされること で，極めて明確に理解できるように工夫されている。こうした詳細な記述・分析を ベースとして, 既存研究からはこぼ落ちていた, 対話もシステムも正義も介在し ない資源管理問題という課題の独自性, それをとらえるための理論的視角の独自性 が十分に明らかにされているといえる，もっとも，本書で提示される「『農民との 良好な関係』といった論理」「農民の日常的感覚」などの概念で説明される内容が ややイメージしにくく感じられるかもしれないが, 序章と終章のまとめの部分の内 容を合わせて読むことで，その意味をつかむことができる.

このようなオリジナリティとともに, 本書の射程は, 「対話アプローチ」「システ ムアプローチ」「正義アプローチ」という 3 つの既存の理論的視角の刷新にも及ぶ ものと考えられる. また,「はじめに」で論じられているように,「成功事例」を取 り上げるのでもなく, 失敗から成功への転換を学ぶのではない形で, あえて「失敗 事例」として位置付けられるような調查地でのフィールドワークを続ける方法論も 大変興味深い，その意味で，自然資源管理をめぐる議論に関心をもつ者にとっては 当然だが, 本書の関心の中心である「現代の暮らしにある身近な対立と折り合って いくすべ」にかかわる研究を行うすべての者にとって, 新たな示唆を得ることので きる研究と思われる.

堀川三郎 著

『町並み保存運動の論理と帰結—小樽運河問題の社会学的分析』

(東京大学出版会, 2018 年, A5 判, 506 頁, 8,000 円+税)

矢部 拓也 (徳島大学総合科学部教授)

本書は，本文 411 頁，文献・資料を含めると 506 頁に及ぶ大作である。それもそ のはず, 著者が最初に小樽と出会ったのは 1984 年 3 月 27 日, それから今日まで 30 余年，小樽と関わり続けてきた集大成であり，小標が現在も変化の途中である 